\title{
Study on the Influencing Factors of Business Success Variables of Technology Startup Entrepreneurs
}

\author{
Seok-Soo $\mathrm{Kim}^{1} \&$ Yen-Yoo $\mathrm{You}^{2}$ \\ ${ }^{1}$ Dept. of Knowledge Service \& Consulting, Hansung University, Seoul, South Korea \\ ${ }^{2}$ Division of Smart Management Engineering, Hansung University, Seoul, South Korea \\ Correspondence: Yen-Yoo You, Professor, Division of Smart Management Engineering, Hansung University, Seoul, \\ South Korea. Tel: 82-10-5201-7743. E-mail: threey0818@ hansung.ac.kr
}

Received: April 9, 2020

Accepted: May 9, 2020

Online Published: May 23, 2020

doi:10.5430/rwe.v11n2p170

URL: https://doi.org/10.5430/rwe.v11n2p170

\begin{abstract}
Background/Objectives: The impact of demographic factors on the business performance of entrepreneurs was investigated and the results suggest the direction of government's employment policy for strengthening, revitalizing the entrepreneurial ecosystem.

Methods/Statistical analysis: We surveyed 300 young start-up entrepreneurs, 205 questionnaires were collected and analyzed using SPSS 22 and Smart PLS 3.2.9. Measurement and structural models were analyzed to evaluate path coefficients and structural suitability. Among the demographic variables, gender was introduced as a control variable, and PLS-Algorithm and Bootstrapping were performed on 8 independent paths and parameters to verify and confirm the difference in the moderating effect according to gender.

Findings: We analyzed the measurement model to analyze internal consistency reliability, focused validity and discriminant validity, and validated the structural model by evaluating the importance and suitability of the determinants $\left(\mathrm{R}^{2}\right)$ : effect size $\left(\mathrm{f}^{2}\right)$ : multicollinearity (Inner VIF): and path coefficients. As a result of estimating the path coefficients (mean, STDEV, T-value, P-value, confidence interval): $\mathrm{EX}-\mathrm{S} \rightarrow \mathrm{TM}-\mathrm{A}, \mathrm{NW}-\mathrm{C} \rightarrow \mathrm{TECH}-\mathrm{P}, \mathrm{NW}-\mathrm{C} \rightarrow$ TIC-A, NW-C $\rightarrow$ TM-A, TCC-C $\rightarrow$ TC-A, TECH-C $\rightarrow$ TC-A, TECH-C $\rightarrow$ TECH-P, TECH-C $\rightarrow$ TIC-A, $\mathrm{TECH}-\mathrm{C} \rightarrow \mathrm{TM}-\mathrm{A}$ has been adopted. In this paper, as a result of the analysis of the regulatory effect, which is a key differentiating factor from previous studies, among the 8 demographic variables, such as gender, type of manufacturing, start-up period, etc. TECH-C-GENDER $\rightarrow$ TECH-P, MGC-DIV $\rightarrow$ TECH-P and TECH-C-YEAR $\rightarrow$ TECH-P were found to have a significant impact on business performance. In conclusion, the results of structural modeling of the factors that affect the business success of technology startups contribute to the establishment of start-up policies for start-up agencies and governments.
\end{abstract}

Improvements/Applications: We will break down the technology sector into manufacturing, non-manufacturing, IT, AI, and big data and add data group analysis on demographic variables to conduct research on more advanced topics.

Keywords: business success variables, technology startup entrepreneurs, business performance, entrepreneurial competency, entrepreneurial influencing factors

\section{Introduction}

The OECD similarly defines an innovator as a company that introduces a new or technologically advanced product or process during the covered period (OECD-Eurostat, 1997): which is a series of innovation activities (Castles, 1997). These are companies that have been successfully completed and earned their innovations. Technology-intensive SMEs are defined as SMEs seeking competitive advantage based on relatively superior unique technologies (Granstrand, 1998). Among SMEs in the high-tech industry, companies with one or more of the following characteristics are defined as technology-intensive small businesses (Giudici and Paleari, 2000). Input indicators, such as R \& D personnel and R $\&$ D investments, which represent technology development capabilities, and output indicators, such as patents and new products, are used as criteria. New technology-based SMEs are the most representative forms of technology-intensive SMEs, which are technology-intensive SMEs founded for the purpose of commercializing new technologies in universities and research institutes. These SMEs are typical of entrepreneurial innovation, as described by J. A. Schumpeter and represented as small, high-growth firms (Khan and Manopichetwattana, 1989). Technology-based 
start-up or venture firms not only play a role as a growth engine to generate innovative results in the industrial sector, but also play a role in driving national economic development (Autio, 1997; Kortum and Lerner, 2001).

\section{Materials and Methods}

\subsection{Technology Startup Success Variables}

\subsubsection{Management Capabilities}

In SMEs, managerial capability is defined as technology, knowledge, and culture that is effective in a specific job and can express management performance, and refers to a term that includes almost everything that directly or indirectly affects the performance of a company (Abatecola et al., 2013). Early SMEs do not have an accurate organization, which limits their ability to generate results based on their capabilities. While management competencies are measured differently in each study, technical and strategic thinking competencies and organizational competencies are considered to be very important (Andreou et al., 2017).

\subsubsection{Technical Capabilities}

Proposed seven types of corporate technology capabilities: learning capacity, R \& D capacity, resource allocation capacity, production capacity, organizational capacity and strategic planning capacity (Yam et al., 2004). Technical capabilities can be defined as all technical capabilities related to product development and production and includes knowledge and techniques necessary for the selection, acquisition, improvement and utilization of technologies (Barney, 1991).

\subsubsection{Network Capabilities}

A company's network capability is the overall capacity to discover and connect with appropriate network targets to absorb external resources and use them to fit the company's situation (Walter et al., 2006). We defined network capability as the ability to interact with other firms, the degree of interactivity and intimacy among firms, and examined the impact of relationship competence, trust and ties on the international performance of high-tech companies (Kenny and Fahy, 2013).

\subsubsection{Technology Commercialization Capabilities}

In the context of new product development strategies, companies that have successfully introduced new products to the market while developing technology commercialization capabilities have been systematically formulated in the process of developing new products. The ability to commercialize technology has been reported to affect management performance (Booz, 1982).

\subsubsection{Exit Strategy Capabilities}

This cross-enterprise network serves as a competitive advantage for companies by allowing them to pursue new alliances with trusted partners (Kogut et al., 1992; Gulati and Gargiulo, 1999). This helps to solve the problem of various information uncertainties. In this regard, previous studies mainly focused on public disclosure (Stuart et al., 1999; Shin et al., 2004).

\subsection{Technology-Based Entrepreneurship Competency}

The three sub-factors of technology-based entrepreneurship discussed in the previous study are as follows.

\subsubsection{Technology Commercialization Competency}

From the resource-based perspective (RBV): we examined the impact of incubation and VC support and technology commercialization on factors that influence the performance of new ventures. The role of technology commercialization as a parameter of the organization's resources, innovation capacity and venture business performance is emphasized (Wu et al., 2008). Analyzed 119 companies on the effect of internal and external resource use on the successful commercialization of technology, and found that internal personnel and technology-based manufacturing sources have a positive relationship with technology commercialization. Integration mechanisms have been shown to play an important regulatory role between resource capacity and technology commercialization (Zahra and Nielsen, 2002).

\subsubsection{Technology Innovation Competency}

Technological innovation competency is a very important competency that drives the company's continuous growth, and at the same time, it is a comprehensive enterprise characteristic that promotes and supports technological innovation (Burgelman et al., 2004). Research on technological innovation has described that companies can create competitiveness and management performance through strategies or research and development that are difficult to 
imitate based on the management resources they hold (Acs and Audretsch, 1988).

\subsubsection{Technology Marketing Competency}

The result of analyzing the success and failure factors of technology development reduces the importance of marketing. In other words, about $20-40 \%$ of defects in technology itself are caused by defects in the technology itself (Miller and Power, 2005): and the rest is due to lack of marketing ability, especially in the case of high-tech products. The resulting ratio is as high as $75 \%$ (Clugston, 1995). Although the interpretation of the term technology marketing varies, the US National Technology Transfer Center (NTTC) broadly defines it as a comprehensive effort to effectively transfer or trade the technology itself (Carr, 1994).

\subsection{Business Performance (Technical Performance)}

Technical performance has a significant impact on technology and technical management capacity production support, marketing capabilities research and development capabilities, and new product development capabilities, and has a significant impact on business performance as well as market intelligence. And having good technology is directly related to the growth or profitability of venture firms and can be an investment determinant of venture capital and other investment firms (Johannisson, 1986).

\section{Results and Discussion}

\subsection{Research Model}

The success factors of technology start-ups have been found to be not only an impact relationship between technology start-up capability and business performance, but also an influential factor. This is one of the earliest achievements of this study, as it can be used to establish and develop country-based policies to expand business base and create jobs. Previous studies and analyzes show that the subfactors of the company's success factors are independent variables for the company's technical performance. The dependencies of the company's success factors are the five sub-factors of technology competency, network competency and technology commercialization competency. As a parameter, the sub-elements of the entrepreneur competency are set up in two sub-elements: the technology commercialization capability and the technology innovation capability. Technical performance was set as a dependent variable. In addition, the effect of the adjustment on the Gender was verified and the results are shown in Figure 1.

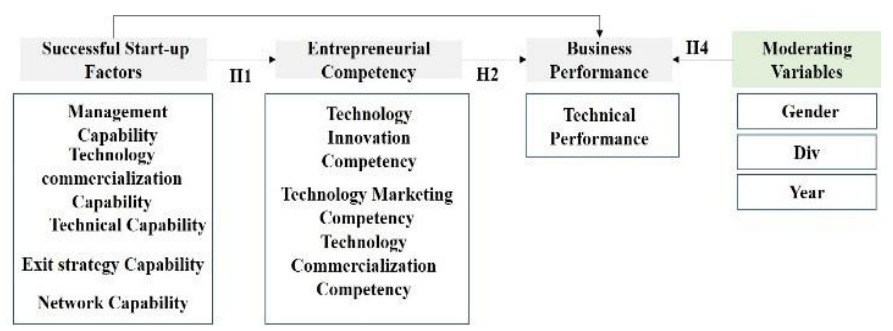

Figure 1. Research model

\subsection{Setting up a Research Hypothesis}

[Hypothesis H1] Successful start-up factors will have a positive impact on technology start-up capability. [Hypothesis H2] Entrepreneurial competence will have a positive impact on technical performance. [Hypothesis H3] Successful start-up factors will have a positive impact on technical performance. [Hypothesis H4] Demographic variables will have a positive effect on technical performance.

\subsection{Research Methods}

\subsubsection{Design of Structural Model}

In this study, a survey was conducted by a technology-based young entrepreneur CEO under 39 years of age. The number of CEOs surveyed was 330, the number of respondents was 205 , and the recovery rate was $62.1 \%$. The collected data was analyzed using SPSS 22 and Smart PLS 3.2.9. Measurement and structural models were analyzed to assess the importance and suitability of path coefficients between variables. The result is shown in Figure 2.

\subsubsection{Structure Model Decision}

The initial research model, as shown in Figure 2, analyzed the factor analysis of exogenous variables (measured 
variables) among variables, evaluated the importance and suitability, and completed the final structural model excluding insignificant measured variables. The results are shown in Figure 3.

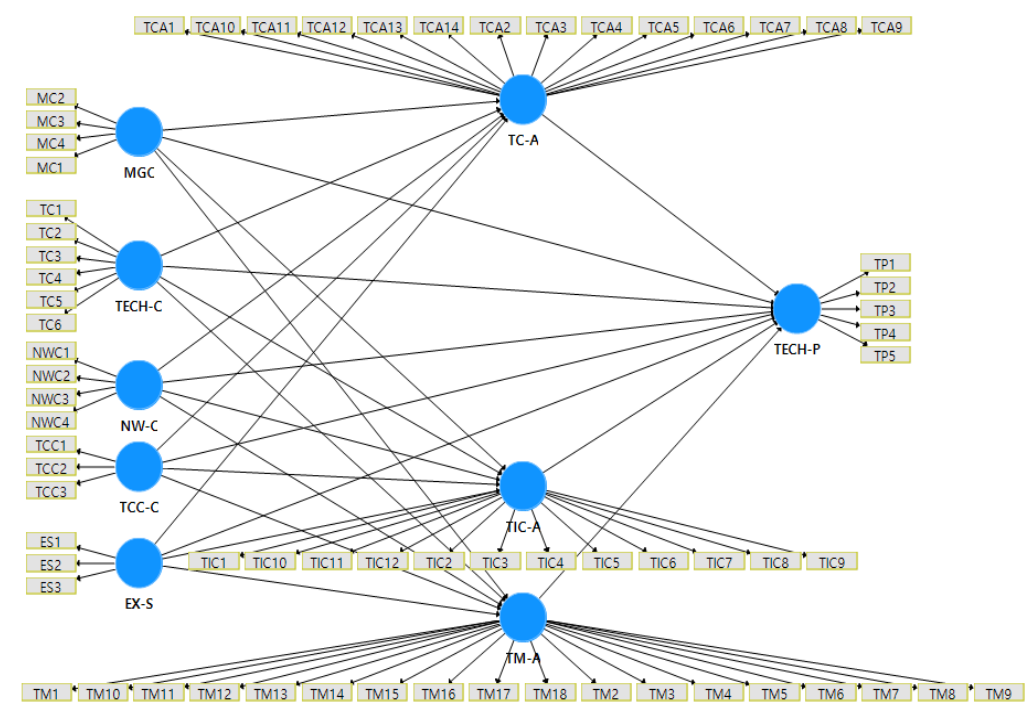

Figure 2. Initial structural model (Before remove variables)

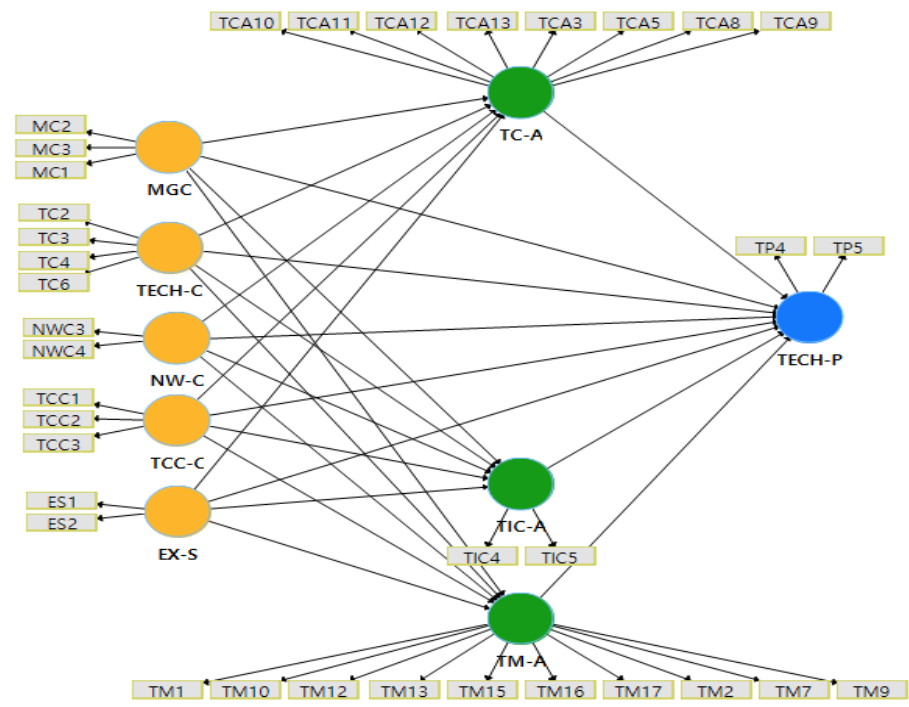

Figure 3. Final structural model (After remove variables)

\subsection{Evaluation of Measurement Model}

PLS Algorithm of Smart PLS 3.0 was executed to analyze and evaluate the internal consistency reliability, concentration validity and discriminant validity. Cronbach's Alpha, Dijkstra-Henseler's rho_A, Composite reliability, AVE, Outer loadings. It was confirmed that the study variables had internal consistency confidence. The measurement model evaluation results are shown in Table 1. 
Table 1. Evaluation of measurement model

\begin{tabular}{ccccccccc}
\hline & \multicolumn{2}{c}{ Convergent Validity } & \multicolumn{2}{c}{ Internal Consistence Reliability } & $\begin{array}{c}\text { Discriminant } \\
\text { Validity }\end{array}$ \\
\cline { 2 - 9 } $\begin{array}{c}\text { Latent } \\
\text { Variables }\end{array}$ & $\begin{array}{c}\text { Outer } \\
\text { Loadings }\end{array}$ & $\begin{array}{c}\text { Measurement } \\
\text { Variables } \\
\text { Reliability }\end{array}$ & AVE & $\begin{array}{c}\text { Cronbach' Dijkstra-Hen } \\
\text { s Alpha } \\
\text { seler's rho_A }\end{array}$ & $\begin{array}{c}\text { Composite } \\
\text { Reliability } \\
\text { (CR) }\end{array}$ & $\begin{array}{c}\text { Cross } \\
\text { Loadings }\end{array}$ \\
\cline { 2 - 9 } & $>0.7$ & $>0.5$ & $>0.5$ & $0.5 ~ 0.9$ & $>0.7$ & $0.5 \sim 0.9$ & 0.95 \\
\hline EX-S & 0.951 & 0.905 & 0.905 & 0.895 & 0.897 & Yes \\
\hline MGC & 0.853 & 0.728 & 0.733 & 0.817 & 0.846 & 0.891 & Yes \\
\hline NW-C & 0.951 & 0.905 & 0.905 & 0.895 & 0.895 & 0.95 & Yes \\
\hline TC-A & 0.888 & 0.789 & 0.691 & 0.936 & 0.937 & 0.947 & Yes \\
\hline TCC-C & 0.831 & 0.69 & 0.712 & 0.799 & 0.834 & 0.881 & Yes \\
\hline TECH-C & 0.842 & 0.709 & 0.789 & 0.911 & 0.911 & 0.937 & Yes \\
\hline TECH-P & 0.953 & 0.908 & 0.908 & 0.899 & 0.899 & 0.952 & Yes \\
\hline TIC-A & 0.957 & 0.916 & 0.916 & 0.91 & 0.975 & 0.956 & Yes \\
\hline
\end{tabular}

Table 2. Multicollinearity (Inner VIF Value)

\begin{tabular}{|c|c|c|c|c|c|c|c|}
\hline & EX-S & MGC & NW-C & TC-A & TCC-C TECH-C TECH-P & TIC-A & TM-A \\
\hline EX-S & & & & 2.853 & 3.081 & 2.853 & 2.853 \\
\hline MGC & & & & 3.808 & 3.943 & 3.808 & 3.808 \\
\hline NW-C & & & & 2.968 & 3.559 & 2.968 & 2.968 \\
\hline TC-A & & & & & 4.371 & & \\
\hline TCC-C & & & & 2.081 & 3.292 & 2.081 & 2.081 \\
\hline TECH-C & & & & 2.394 & 3.03 & 2.394 & 2.394 \\
\hline TIC-A & & & & & 1.621 & & \\
\hline TM-A & & & & & 3.716 & & \\
\hline
\end{tabular}

\subsection{Evaluation of Structural Model}

To verify the significance of the measurement model, multi-collinearity, coefficient of determination $\left(\mathrm{R}^{2}\right)$ : effect size $\left(\mathrm{f}^{2}\right)$ : and predictive suitability $\left(\mathrm{Q}^{2}\right)$ were performed, and reviewed, confirmed and evaluated. The results are shown in Tables 2-5 (Abdel, 2017); (Adedoyin and Okere, 2017). Table 2 shows the results of verifying the inner VIF value by executing PLS algorithm to confirm multicollinearity. If the inner VIF Values among the study variables are less than 5 , it can be judged that there is no multicollinearity. As a result, all of them are less than 5, so there is no multicollinearity. Evaluate the explanatory power of exogenous study variables (or predictors, independent variables): the coefficient of determination $\mathrm{R}^{2}$ is used. If $\mathrm{R}^{2}$ value is 0.25 , it is evaluated as weak explanatory power, 0.5 for medium explanatory power, and 0.75 for large explanatory power. In order to evaluate the explanatory power of the endogenous research variables, the results of verifying the coefficient of determination $\mathrm{R}^{2}$ by executing the PLS algorithm are shown in Table 3 . 
Table 3. Evaluation $\mathrm{R}^{2}$

\begin{tabular}{crr}
\hline & R Square & \multicolumn{2}{c}{ Adjusted R Square } \\
\hline TC-A & 0.765 & 0.759 \\
\hline TECH-P & 0.590 & 0.573 \\
\hline TIC-A & 0.374 & 0.358 \\
\hline TM-A & 0.721 & 0.714 \\
\hline
\end{tabular}

Table 4. Evaluation effect size $\left(\mathrm{f}^{2}\right)$

\begin{tabular}{|c|c|c|c|c|}
\hline & TC-A & TECH-P & TIC-A & TM-A \\
\hline EX-S & 0.001 & 0.001 & 0.015 & 0.071 \\
\hline MGC & 0.029 & 0.021 & 0.002 & 0.006 \\
\hline NW-C & 0.017 & 0.091 & 0.064 & 0.151 \\
\hline TC-A & & 0.006 & & \\
\hline TCC-C & 0.52 & 0.013 & 0.024 & 0.002 \\
\hline TECH-C & 0.076 & 0.126 & 0.094 & 0.155 \\
\hline TIC-A & & 0.023 & & \\
\hline TM-A & & 0.000 & & \\
\hline
\end{tabular}

Table 5. Predictive relevance $\left(\mathrm{Q}^{2}\right)$

\begin{tabular}{|c|c|c|c|}
\hline & SSO & SSE & $\mathrm{Q}^{2}(=1-\mathrm{SSE} / \mathrm{SSO})$ \\
\hline TC-A & $1,632.00$ & 840.046 & 0.485 \\
\hline TECH-P & 408 & 211.538 & 0.482 \\
\hline TIC-A & 408 & 282.251 & 0.308 \\
\hline TM-A & $2,040.00$ & $1,109.45$ & 0.456 \\
\hline
\end{tabular}

Evaluate the relative influence of exogenous study variables (or predictors, independent variables) on endogenous study variables, ie the extent to which exogenous study variables contribute to $\mathrm{R}^{2}$ of endogenous study variables. For this purpose, the effect size $\left(\mathrm{f}^{2}\right)$ is used. Evaluate whether the structural model has predictive suitability for specific endogenous study variables, predictive suitability $\left(\mathrm{Q}^{2}\right)$ is used. Blindfolding of Smart PLS 3.2.9 was performed to confirm the results of Cross-Validated Redundancy and to evaluate $\mathrm{Q}^{2}$. The results are shown in Table 4-5.

\subsection{Hypothesis Verification Results}

In order to confirm the significance of the measurement model, the significance and suitability of the path coefficient are evaluated using the t-value calculated by PLS Bootstrapping in PLS 3.2.9. In conclusion, hypothesis verification can be performed. The results of the hypothesis verification are shown in Table 6.

Table 6. Evaluation of hypothesis test

\begin{tabular}{|c|c|c|c|c|c|c|c|c|}
\hline & $\begin{array}{l}\text { Original } \\
\text { Sample }\end{array}$ & $\begin{array}{c}\text { Sample } \\
\text { mean }\end{array}$ & $\begin{array}{c}\text { Standard } \\
\text { Deviation }\end{array}$ & $\mathrm{T}$ statistics & P Value & $\begin{array}{r}\text { Confi } \\
\text { Inte }\end{array}$ & $\begin{array}{l}\text { dence } \\
\text { rval }\end{array}$ & Significance \\
\hline & $(\mathrm{O})$ & $(\mathrm{M})$ & (STDEV) & $\overline{(|\mathrm{O} / \mathrm{STDEV}|)}$ & & $2.50 \%$ & $97.50 \%$ & $(\mathrm{p}<0.05)$ \\
\hline $\mathrm{EX}-\mathrm{S} \rightarrow \mathrm{TM}-\mathrm{A}$ & 0.237 & 0.229 & 0.104 & $4 \quad 2.277$ & 0.023 & 0.026 & 0.428 & Yes \\
\hline $\mathrm{NW}-\mathrm{C} \rightarrow \mathrm{TECH}-\mathrm{P}$ & 0.364 & 0.355 & 0.121 & 2.994 & 0.003 & 0.107 & 0.583 & $\overline{\text { Yes }}$ \\
\hline $\mathrm{NW}-\mathrm{C} \rightarrow \mathrm{TIC}-\mathrm{A}$ & 0.344 & 0.345 & 0.126 & 2.730 & 0.006 & 0.096 & 0.578 & Yes \\
\hline $\mathrm{NW}-\mathrm{C} \rightarrow \mathrm{TM}-\mathrm{A}$ & 0.353 & 0.362 & 0.092 & 3.860 & 0.000 & 0.173 & 0.533 & $\overline{\text { Yes }}$ \\
\hline $\mathrm{TCC}-\mathrm{C} \rightarrow \mathrm{TC}-\mathrm{A}$ & 0.505 & 0.508 & 0.065 & 7.799 & 0.000 & 0.365 & 0.621 & $\overline{\text { Yes }}$ \\
\hline TECH-C $\rightarrow$ TC-A & 0.206 & 0.202 & 0.077 & 2.680 & 0.007 & 0.047 & 0.346 & Yes \\
\hline $\begin{array}{c}\text { TECH-C } \rightarrow \\
\text { TECH-P }\end{array}$ & 0.395 & 0.392 & 0.112 & 3.519 & 0.000 & 0.172 & 0.619 & Yes \\
\hline TECH-C $\rightarrow$ TIC-A & 0.374 & 0.377 & 0.108 & 3.461 & 0.001 & 0.171 & 0.584 & Yes \\
\hline TECH-C $\rightarrow$ TM-A & 0.321 & 0.327 & 0.084 & 3.842 & 0.000 & 0.153 & 0.483 & Yes \\
\hline
\end{tabular}


The exit strategy is $\mathrm{EX}-\mathrm{S} \rightarrow \mathrm{TM}-\mathrm{A}$ (path coefficient .237): the network capability is NW-C $\rightarrow$ TECH-P (path coefficient .364): NW-C $\rightarrow$ TIC-A (path coefficient.344): NW-C $\rightarrow$ TM-A (path coefficient.353): the technology commercialization capability is TCC-C $\rightarrow$ TC-A (path coefficient .505): and technology capability is TECH-C $\rightarrow$ TC-A (path coefficient .206): TECH-C $\rightarrow$ TECH-P (path coefficient .395): TECH-C $\rightarrow$ TIC-A (path coefficient .374): TECH-C $\rightarrow$ TM-A(Path coefficients .321) all four paths were found to affect. The results of the smart PLS implementation for the verification of the measurement model and the structural model of the research model are shown in Figures 4-6. Figures 5 and 6 show the different paths that affect technical performance by Gender (1: male, 2: female).

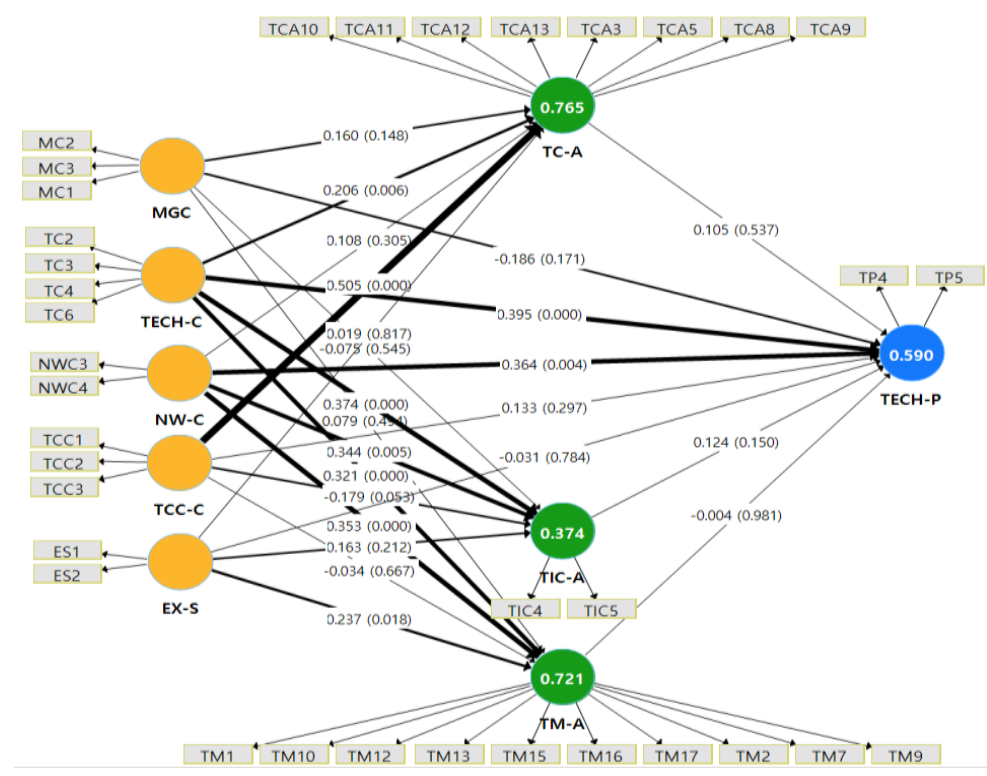

Figure 4. Bootstrapping result

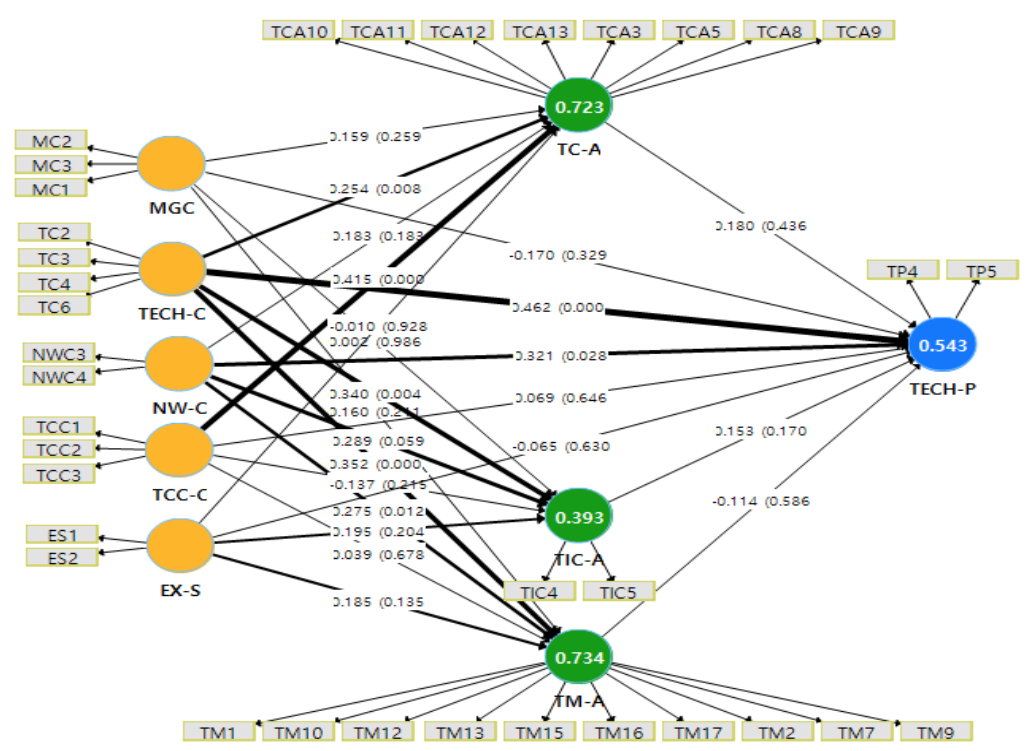

Figure 5. Bootstrapping (Gender1) 


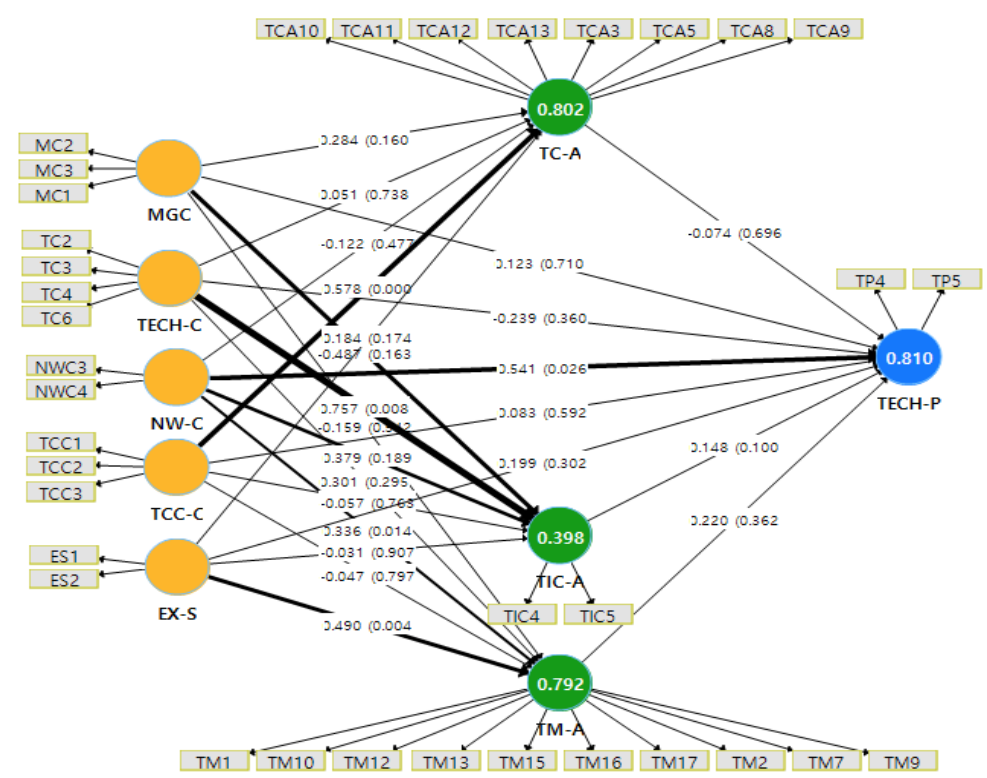

Figure 6. Bootstrapping (Gender 2)

\subsection{Moderation Effect Verification}

In order to confirm the adjustment effect on the business performance of the demographic variable (Gender): the results of verifying each adjustment effect by Bootstrapping of Smart PLS 3.2.9 are shown in Figures 7-9. The results of confirming the change in $\mathrm{R}^{2}$ and $\mathrm{f}^{2}$ influence of each control effect are shown in Tables 7-9 (Aemiro, 2019); (Afzal et al., 2019); (Ali, 2017). In Table 7, $\mathrm{R}^{2}$ for technical performance decreased from .59 to .54 for Gender 1 (male): while it increased from .590 to .810 for Gender 2 (female). In Table 8 , Gender 1 in the case of males, $\mathrm{f}^{2}$, the size of the effect on technical performance, increased from .126 to .183, which is a strong effect, while in Gender 2 (female): it decreased from .126 to .046. In the case of NW-C, Gender 2 (female) showed a strong effect size from Non-Gender .091 to .267.

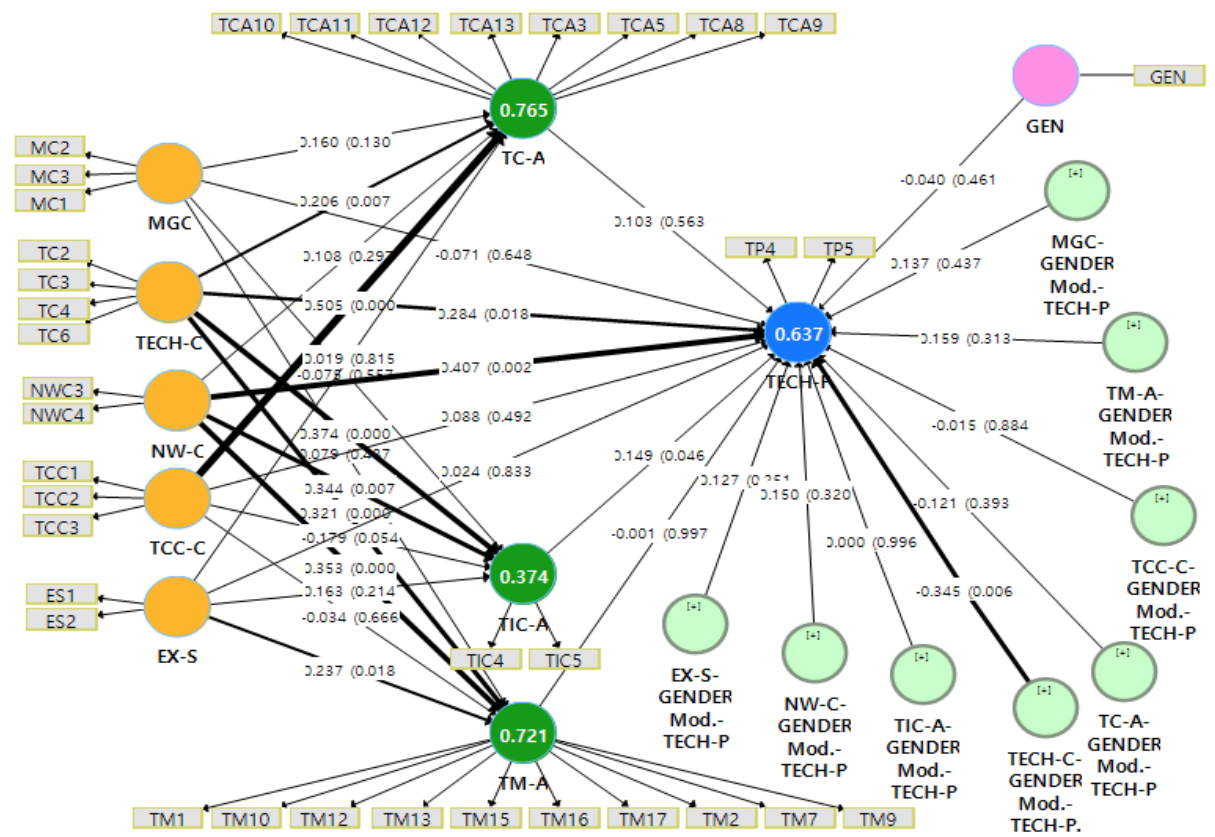

Figure 7. Bootstrapping (Moderator: Gender) 


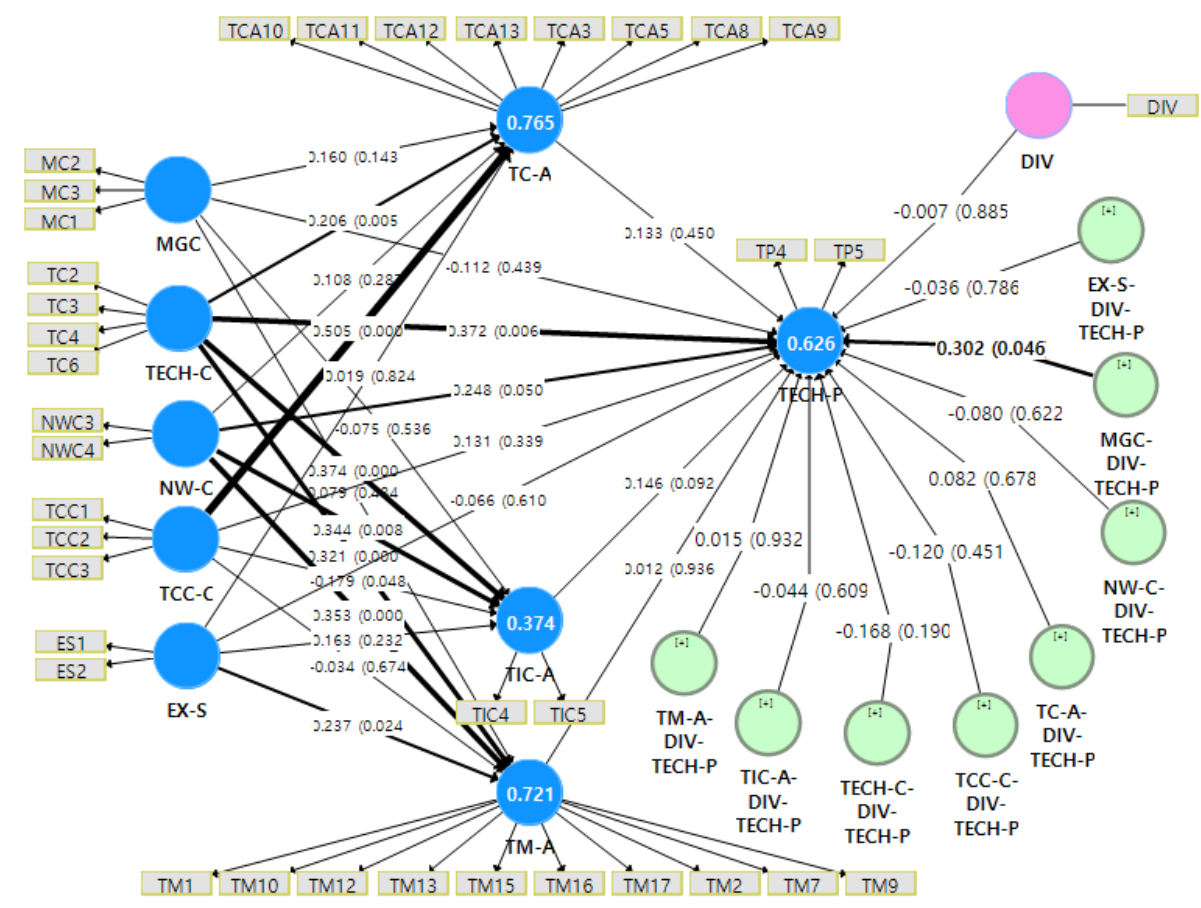

Figure 8. Bootstrapping (Moderator: Division)

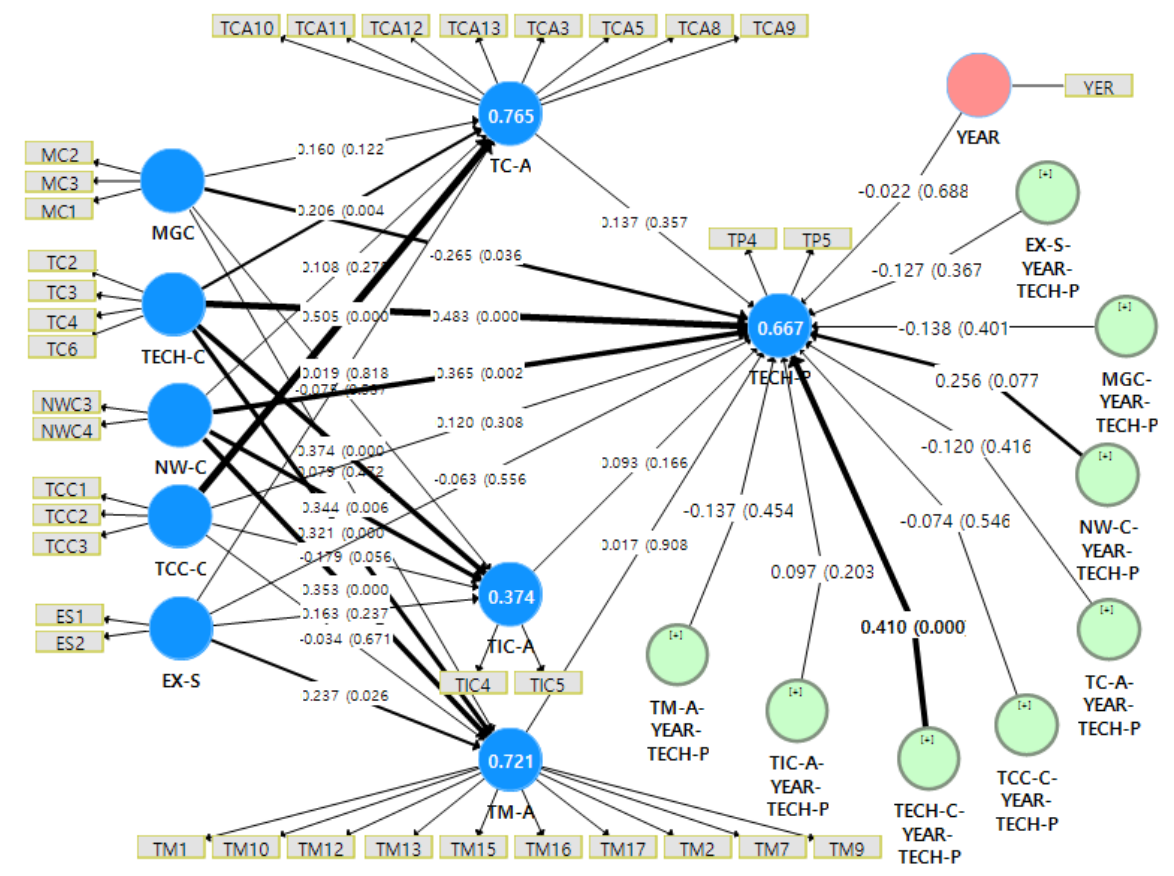

Figure 9. Bootstrapping (Moderator: Year) 
Table 7. Result of moderation effect (Change in $\mathrm{R}^{2}$ depend on Gender1,2 vs non-Gender)

\begin{tabular}{|c|c|c|c|c|c|c|c|c|}
\hline & \multicolumn{2}{|c|}{ Non- Gender } & & \multicolumn{2}{|c|}{ Gender 1(male) } & & \multicolumn{2}{|c|}{ Non- Gender 2(female) } \\
\hline & $\begin{array}{c}\mathbf{R} \\
\text { Square }\end{array}$ & $\begin{array}{l}\text { Adjusted R } \\
\text { Square }\end{array}$ & & $\begin{array}{c}\mathbf{R} \\
\text { Square }\end{array}$ & $\begin{array}{c}\text { Adjusted R } \\
\text { Square }\end{array}$ & & $\begin{array}{c}\mathbf{R} \\
\text { Square }\end{array}$ & $\begin{array}{l}\text { Adjusted R } \\
\text { Square }\end{array}$ \\
\hline TC-A & 0.765 & 0.759 & TC-A & 0.723 & 0.712 & TC-A & 0.802 & 0.787 \\
\hline TECH-P & 0.59 & 0.573 & TECH-P & 0.543 & 0.514 & TECH-P & 0.81 & 0.785 \\
\hline TIC-A & 0.374 & 0.358 & TIC-A & 0.393 & 0.37 & TIC-A & 0.398 & 0.351 \\
\hline TM-A & 0.721 & 0.714 & TM-A & 0.734 & 0.723 & TM-A & 0.792 & 0.775 \\
\hline
\end{tabular}

Table 8. Result of moderation effect (Change in $\mathrm{f}^{2}$ depend on Gender1,2 vs non-Gender)

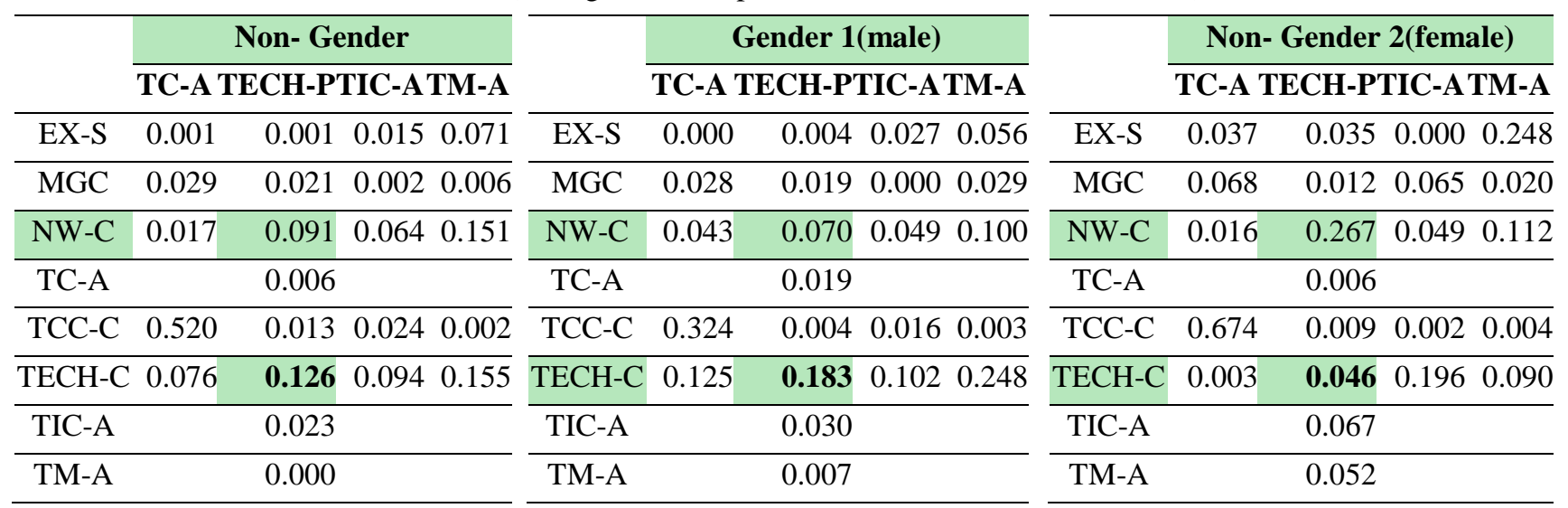

Figure 7 shows a significant moderating effect on technical performance (TECH-C-GENDER $\rightarrow$ TECH-P) as a result for Gender. Figure 8 shows a significant moderating effect on technological performance (MGC-DIV $\rightarrow$ TECH-P) as a result of the business type of the firm. Figure 9 shows a significant moderating effect on technical performance (TECH-C-YEAR $\rightarrow$ TECH-P) as a result of the number of years of business. The results are shown in Table 9.

Table 9. Result of moderation effect verification

\begin{tabular}{|c|c|c|c|c|c|c|c|c|}
\hline & $\begin{array}{l}\text { Original } \\
\text { Sample }\end{array}$ & $\begin{array}{l}\text { Sample } \\
\text { mean }\end{array}$ & $\begin{array}{l}\text { Standard } \\
\text { Deviation }\end{array}$ & $\mathrm{T}$ statistics & $\mathrm{P}$ & $\begin{array}{r}\text { Con } \\
\text { Int }\end{array}$ & $\begin{array}{l}\text { fidence } \\
\text { terval }\end{array}$ & Significance \\
\hline & $(\mathrm{O})$ & $(\mathrm{M})$ & (STDEV) & $(|\mathrm{O} / \mathrm{STDEV}|)$ & & $2.50 \%$ & $97.50 \%$ & $(p<0.05)$ \\
\hline $\begin{array}{l}\text { TECH-C-GENDER } \rightarrow \\
\text { TECH-P }\end{array}$ & -0.345 & -0.334 & 0.132 & 2.609 & 0.009 & -0.595 & -0.088 & Yes \\
\hline MGC-DIV $\rightarrow$ TECH-P & 0.302 & 0.290 & 0.152 & 1.981 & 0.048 & 0.041 & 0.624 & Yes \\
\hline $\begin{array}{l}\text { TECH-C-YEAR } \rightarrow \\
\text { TECH-P }\end{array}$ & 0.410 & 0.397 & 0.114 & 3.591 & $\mathbf{0 . 0 0 0}$ & 0.208 & 0.631 & Yes \\
\hline
\end{tabular}

\section{Conclusion}

This paper identifies the factors that affect the performance of technology entrepreneurs, especially the technological performance, and examines the moderating effects on technological performance on demographic factors such as gender, type of firm, and number of years of business. The influence and difference were also verified. As a result of hypothesis testing, four factors and pathways were found to have significant influence factors and pathways on technical performance. 1)Exit strategy is EX-S $\rightarrow$ TM-A 2)Network capacity is NW-C $\rightarrow$ TECH-P, NW-C $\rightarrow$ TIC-A 3)Technology commercialization capacity is TCC-C $\rightarrow$ TC-A 4)Technology capacity is TECH-C $\rightarrow$ TC-A, $\mathrm{TECH}-\mathrm{C} \rightarrow \mathrm{TECH}-\mathrm{P}, \mathrm{TECH}-\mathrm{C} \rightarrow \mathrm{TIC}-\mathrm{A}, \mathrm{TECH}-\mathrm{C} \rightarrow \mathrm{TM}-\mathrm{A}$. This result confirms that the technical ability of the founding entrepreneur is important by verifying that the technical ability, which is one of the success variables in which the technical performance is an independent variable, is affected by four channels. In addition, network 
capability, technology commercialization capability, and exit strategy were also found to be significant factors. Among the demographic variables, we found that gender, firm type, and number of years of firms influence technological performance as moderating factors. The result of the verification, which was not carried out in the previous research, contributes to the establishment of a start-up policy for start-up support agencies and government policy makers. In future research, detailed analysis by gender, company type, and company years will be conducted to further suggest the causes and measures of the difference.

\section{Acknowledgment}

This research was financially supported by Hansung University.

\section{References}

Abatecola, G., Mandarelli, G., \& Poggesi, S. (2013). The personality factor: how top management teams make decisions. A literature review. Journal of Management \& Governance, 17(4), 1073-1100.

Abdel, E. R. (2017). The role of fiscal space in attracting FDI. Asian Journal of Economic Modelling, 5(4), 396-401.

Acs, Z. J., \& Audretsch, D. B. (1988). Innovation in large and small firms: an empirical analysis. The American Economic Review, 678-690.

Adedoyin, O., \& Okere, E. (2017). The significance of inclusion concept in the educational system as perceived by junior secondary school teachers: Implications for teacher training programmes in Botswana. Global Journal of Social Sciences Studies, 3(1), 13-28.

Aemiro, T. (2019). The effect of selected factors on tax revenue mobilization in Ethiopia: The Case of Amhara Region. Economics, 6(2), 110-119.

Afzal, M., Ejaz, S., \& Ahmad, S. (2019). Analysis of domestic versus foreign banks efficiency in Pakistan. Asian Journal of Economics and Empirical Research, 6(1), 36-44. https://doi.org/10.20448/journal.501.2019.61.36.44

Ali, H. E. (2017). Phase transfer synthesis of novel based surfactants: Role of biocorrosion inhibition. Global Journal of Social Sciences Studies, 3(1), 43-55.

Andreou, P.C., Karasamani, I., Louca, C., \& Ehrlich, D. (2017). The impact of managerial ability on crisis-period corporate investment. Journal of Business Research, 79, 107-122.

Autio, E. (1997). New, technology-based firms in innovation networks symplectic and generative impacts. Research Policy, 26(3), 263-281.

Barney, J. (1991). Firm resources and sustained competitive advantage. Journal of Management, 17(1), 99-120.

Booz, A. H. (1982). New products management for the 1980s. Booz, Allen\& Hamilton.

Burgelman, R., Maidique, M., \& Wheelwright, S. (2004). Strategic management of technology and innovation. Times Mirror Higher Education Group.

Carr, R. K. (1994). Doing technology transfer in federal laboratories. In From Lab to Market, Springer, Boston, MA., pp. 61-87.

Castles, I. (1997). Review of the OECD-Eurostat PPP Program. report commissioned by the OECD. Retrieved from http://www. oecd.org/pdf

Clugston, C. O. (1995). High-Tech demands own new-product plan. Electronic News, 4l(2094), 33-36.

Giudici, G., \& Paleari, S. (2000). The provision of finance to innovation: A survey conducted among Italian technology-based small firms. Small Business Economics, 14(1), 37-53.

Granstrand, O. (1998). Towards a theory of the technology-based firm1. Research Policy, 27(5), 465-489.

Gulati, R., \& Gargiulo, M. (1999). Where do interorganizational networks come from?. American Journal of Sociology, 104(5), 1439-1493.

Johannisson, B. (1986). Network strategies: management technology for entrepreneurship and change. International Small Business Journal, 5(1), 19-30.

Kenny, B., \& Fahy, J. (2013). The role of tie strength, relational capability and trust in the international performance of high tech SMEs. The IMP Journal, 7(3), 188-203.

Khan, A. M., \& Manopichetwattana, V. (1989). Innovative and noninnovative small firms: Types and characteristics. Management Science, 35(5), 597-606. 
Kogut, B., Shan, W., \& Walker, G. (1992). The make-or-cooperate decision in the context of an industry network. Networks and Organizations, 348-365.

Kortum, S., \& Lerner, J. (2001). Does venture capital spur innovation?. In Entrepreneurial inputs and outcomes: New studies of entrepreneurship in the United States (pp. 1-44). Emerald Group Publishing Limited.

Miller, P., \& Power, M. (2005). Calculating corporate failure. Professional Competition and Professional Power. Routledge, 65-90.

Shin, H. H., Chang, J. J., \& Chung, J. W. (2004). IPO underpricing and market stabilization. Asia-Pacific Journal of Financial Studies, 155-190.

Stuart, T. E., Hoang, H., \& Hybels, R. C. (1999). Interorganizational endorsements and the performance of entrepreneurial ventures. Administrative Science Quarterly, 44(2), 315-349.

Walter, A., Auer, M., \& Ritter, T. (2006). The impact of network capabilities and entrepreneurial orientation on university spin-off performance. Journal of Business Venturing, 21(4), 541-567.

Wu, L. Y., Wang, C. J., Chen, C. P., \& Pan, L. Y. (2008). Internal Resources, External Network, and Competitiveness during the Growth Stage: A Study of Taiwanese High-Tech Ventures. Entrepreneurship Theory and Practice, 32(3), 529-549.

Yam, R. C., Guan, J. C., Pun, K. F., \& Tang, E. P. (2004). An audit of technological innovation capabilities in Chinese firms: some empirical findings in Beijing, China. Research Policy, 33(8), 1123-1140.

Zahra, S. A., \& Nielsen, A. P. (2002). Sources of capabilities, integration and technology commercialization. Strategic Management Journal, 23(5), 377-398. 